cloes not only consider the differences of the vibration-rates of pairs of over-tones, but inquires also whether they are within beating distance of each other. In the former case alone can they become a source of clissonance. The interval of an octar'e is a perfect consonance, because every partial-tone of the higher sound coincides with one of those of the lower; and thus any slight deviation in pitch will produce beats betweein each adjacent pair

The interval of a fortrth is less consonant than that of a fifth -not, as Prof. Tynclall represents it, on account of its 65 beats which, but a single octave below that in which he has placed it, ought to become the worst possible dissonance-but because the sccond partial-tone of the higher sound comes within beating clistance (a whole tone) of the third partial-tone of the lower, as shown on the stave-

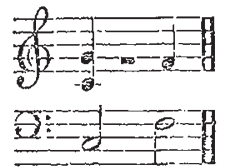

when the fundamental tones are witten in minims, and the over-tones in crotchets.

I may as well notice that a diagram given by Helmholtz * to illustrate various degrees of dissonance, and copied by Prof. Tyndall, $\nmid+$ is accompanied by the latter with an explanntion giving. a wong idea of its meaning. The diagram, as explained by its author, is intended to represent to the eye the clegrces of roughness attaching to intervals greater than one octave, and not exceeding two. Prof. Tyndall having eviclently missed the remark of Helmholtz that $\mathrm{C}^{\prime}$, not its octare $\mathrm{C}^{\prime \prime}$, "is to be the constant fundanental tone of all the intervals," has represented the diagram as "beginning with the unison $\mathrm{C}^{\prime \prime}-\mathrm{C}^{\prime \prime}$ " and going up to the octave intead of beginning with the octave $\mathrm{C}^{\prime}-\mathrm{C}^{\prime \prime}$ and going up to the double octave $C^{\prime}-C^{\prime \prime \prime}$. The diagram as it stands in Prof. Tyndall's lecture is calculated to convey an impression as unlike its author's meaning as it is contrary to fact.

Trinity College, Cambridge, Feb. 26

SEDLEY TAYLOR

\section{The Valuation of Liquid Town Sewage}

THough $\mathrm{I}$ consider it highly unbecoming for one member of a committee, charged with an important inquiry, to criticise publicly and in a controversial manner, views expressed by another member of that committee in regard to the subject it has to investigate, still some of the remarks made by Mr. Hope at the Society of Arts last Wednesday seem so unmistakeably to refer to the article which appeared in NATURE on the $23 \mathrm{rd}$ December last, that I feel constrained, as the writer of that article, to reply to them. The statement objected to by $\mathrm{Mr}$. Hope was an expression, not of individual opinion, but of the factlong accepted as beyond question--that the practical value of liquid town sewage as manure, that is to say, its value to the farmer, cannot be computed solely from the amount of manure material it may contain, and that, in forming such an estimate, the positive element afforded by chemical analysis must be controlled by the negative element introduced by extreme dilution, and varying under different local circumstances. This fact has been recognised by anthorities too numerous to name, and so decisively, that Mr. Hope's assertion as to the value of the ammonia in sewage being affected only in a very minor degree by the amount of water mixed with it, seems to have no other merit than that of being "sensational." I am at a loss to conceive what ground $M x$. Hope could have for objecting to the statement that "it is a great mistake, and likely to prove a very ruinous one," to estimate the value of dilute sewage by calculation solely from the amount of manure material it may contain. Yet this is what Mr. Hope characterises as a "strange paradox." Why it has puzzled him, as he admits, I will not stop to inquire; but I must protest against his representing "the obligation of applying water to crops at all times of the year, whether they want it or not," as having been one of the reasons given for the statement he objects to. In doing that he has at least fallen into a great error, and he has at the same time evaded the point to which attention was directed in the article, viz., the agricultural difficulty attending the "continuous daily application of sewage to land." That is a difficulty not to be disposed of ex cathedra-it would obtain whether the land des-

$$
\text { * The second on page 292. † Page 208. } \quad \ddagger \text { Page 2gr. }
$$

tined to receive semage were under crops or lying fallow. In the one case the application of sewage night be inadmissible during great part of the year; in the other case the land under fallow would be umprodtuclive meanwhile. Indeed the need for applying sewage to fallow land, which Mrr. Hope seems to suggest, would enhance tire difficulty of disposing of sewage by irrigation, since it would involve the want of a still larger area of land for its reception, day by day throughout the year. Such a mode of application might well necessitate an area of twenty-five acres for every 100 persons, and that necessity, if it existed, would be, I imagine, a very sexious matterin the crse of many towns.

I will not attempt to occupy your space by considering the question whether leaving land under fallow is to be regarded as a feature of progress in agriculture; nor will I venture an opinion as to whether water be the "best dung-cart," further than to express my surprise that, in regard to this question, Mr. Hope should have recourse to a chemist's opinion while declaring that its decision is not within the province of the chemists.

The case put by Mr. Hope, with an air of anticipatory triumph, of a man who applies to his land an excessive and useless amount of manure, seens to me an exact parallel to the use of liquid sewage in many instances, for whether it be the fancy or the folly of the farmer, or some other circumstance, which impels him to use manure in such a way that the possible effect cannot come up to the amount of manure applied, I should imagine it to be obvions that, to the user, the value of the manure must be rauged by the practical effect likely to be realised. I should expect this view to be appreciated even by the bucolic intellect which Mr. Hope seems disposed to contemn.

As stated by the chairman at the Society of Arts meeting, the views held by $\mathrm{Mr}$. Hope on the general subject of town refuse are clear and precise. There is no doubt what those views are, but it is not my intention to enter upon any discussion of them. At the same time, as a member of the British Association Conmittee, and having individually entertained the expectation that Mr. Hope's co-operation would be of material service in the inquiry it has to make, I cannot avoid expressing my regret that he declares himself a partisan of one particular solution of the town-refuse problem. There are, probably, few questions of the day which demand more careful and impartial consideration than this one--few that less admit of being dealt with for the promotion of a project at any price, For my own part, therefore, I deem it a misfortune that the value of M $\mathrm{Mr}$. Hope's well-known ability and extensive knowledge of this subject should be limited by his avowal of a foregone conclusion.

February 28.

Benjamin H. Paud

\section{Weeds in Newiy Turned Ground}

From a recent address of Mr. Bentham, the President of the Limman Society, it would appear to be still uncertain whether the weeds which appear spontaneously on ground which has been newly turned over, spring from seeds hiclden in the ground, or from seeds accidentally carried on to the new surface. Could not this question be decided by a simple experiment, namely, by turning over some suitable ground and covering parts of it by gardener's glass frames, so as to prevent the importation of any seeds? So far as the weeds are the same both within and without the frames, it is certain that they must spring from seeds previously contained in the earth. It is true that there will be a difference of temperature beneath the glass and in the open air, but it would not prevent us from learning what seeds are really contained in the earth. A frame covered with fine muslin would serve instead of glass if the muslin be fine enough to prevent the passage of any seeds.

\section{Skeleton Lectures on Science}

I HOPE you will allow me, through your valuable pages, to suggest what I have no doubt would be a most powerful and successful means for promoting scientific knowledge throughout the length and breadth of the land. There are hundreds of persons with the desire and a sufficient taste and general know. ledge of science, who now devote themselves to penny readings, who would be too glad to give popular lectures on scientific subjects, if they could only be aided by skele'on lectures, and the loan, on moderate terms, of simple apparatus, diagrams, \&c., to illustrate the same. It certainly would well remunerate any scientific instrument maker to loan out apparatus for such lectures.

Skeleton sermons are enormously in request, why not skeletcn lectures on science? 